Images in...

\title{
Mysterious but not serious?
}

\author{
Gayle Hann, ${ }^{1}$ Stefanie Catherine Thust, ${ }^{2}$ Emma Devereux ${ }^{1}$ \\ 1Paediatrics Department, North Middlesex University Hospital NHS Trust, London, UK; \\ 2Radiology Department, Guy's and St Thomas' NHS Foundation Trust, London, UK
}

Correspondence to Dr Gayle Hann, gaylehann@yahoo.com

\section{DESCRIPTION}

A previously well 13-year-old boy presented with a 3 -month history of right-sided hip pain responding to

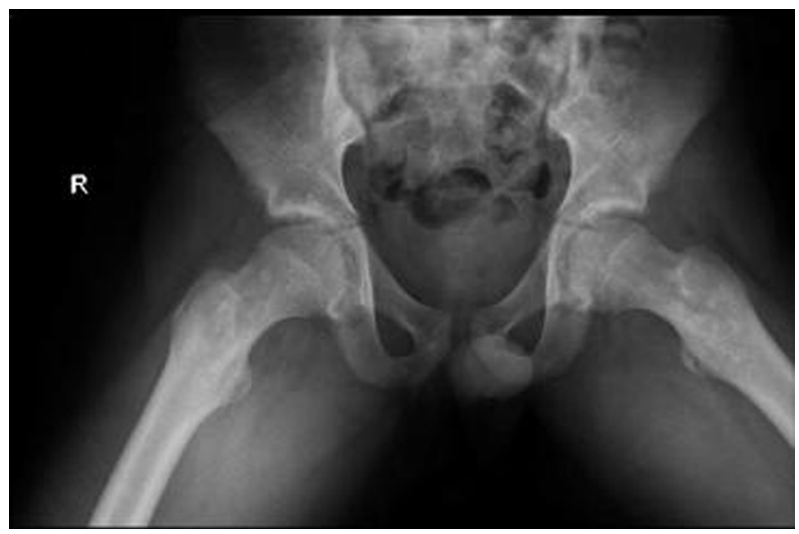

Figure 1 Pelvic $x$-ray demonstrating multiple sclerotic lesions in both femora and pelvis.

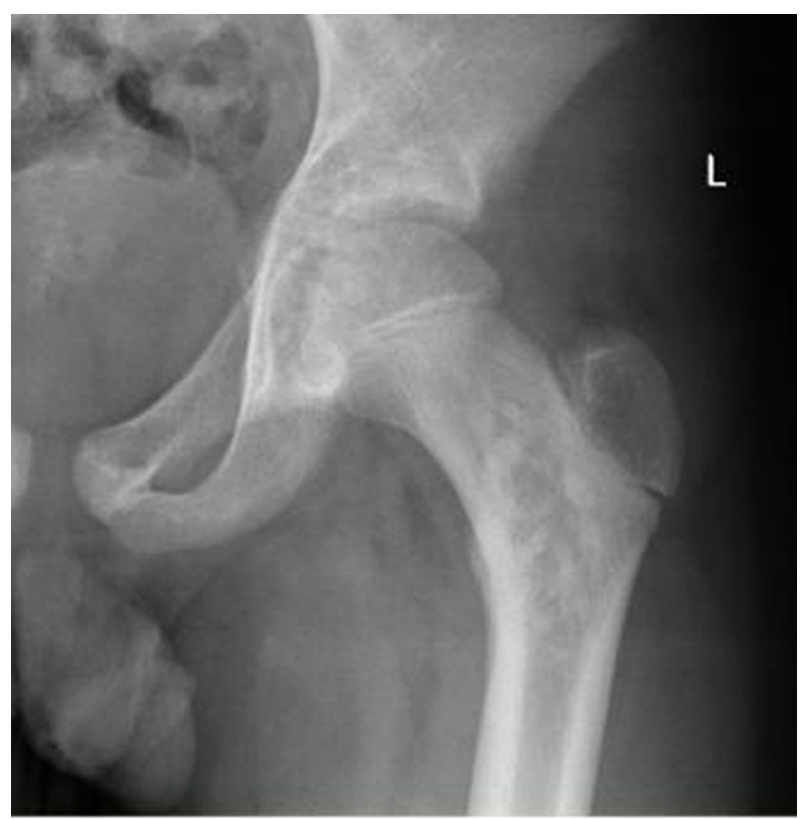

Figure 2 X-ray of the asymptomatic hip featuring multiple sclerotic lesions in the proximal left femur and adjacent pelvis. simple analgesia. Physical examination and blood tests were unremarkable. A pelvic x-ray (figure 1) revealed multiple sclerotic lesions in both femora, worse on the asymptomatic left side (figure 2) with further lesions in the pelvis. Review of a previous $\mathrm{x}$-ray taken for minor trauma 2 years earlier demonstrated similar lesions in the right humerus. Following discussion with radiology, a diagnosis of osteopoikilosis was made. Osteopoikilosis (osteopathia condensans or osteosclerosis fragilis congenita) is an osteosclerotic dysplasia, seen in males and females of all ages but rarely before 3 years of age. ${ }^{1}$ Inherited and sporadic cases have been identified as well as a possible link to dwarfism and dystocia. Genetic studies suggest autosomal dominant inheritance with possible increasing penetrance. ${ }^{2}$ The radiographic findings of osteopoikilosis consist of multiple 3-10 mm, well-defined sclerotic foci ${ }^{2}$ often symmetrically distributed and usually clustered in epiphyses and metaphyses of tubular long bones. Cases of osteosarcoma, chondrosarcoma and giant cell tumours in patients with osteopoikilosis have been reported, although no definite association has been established. ${ }^{1}$ While the imaging appearances of osteopoikilosis are pathognomonic, other conditions may give rise to similar appearances. These include melorrheostosis, osteopathia striata, enostoses, mastocytosis, tuberous sclerosis but also primary bone malignancy and metastases. Importantly, $25 \%$ of osteopoikilosis patients also manifest cutaneous lesions (dermatofibrosis lenticularis disseminate). ${ }^{1}$ Knowledge of the pathognomonic radiographic features of osteopoikilosis can avoid multiple investigations as well as unnecessary anxiety in patient and physician alike. ${ }^{3}$

Acknowledgements The authors would like to thank the patient and family for giving consent for the images to be used.

Competing interests None.

Patient consent Obtained.

\section{REFERENCES}

1. Farbach KC. A fifty year old man with hip pain. Aunt Minnie.com http://www. auntminnie.com/index.asp?sec $=$ sea\&sub $=$ res\&qu $=$ osteopoikilosis $q S e a r c h S$ ec $=$ all $(14$ October 2011).

2. Melnick JC. Osteopathia condensans disseminata (osteopoikilosis); study of a family of 4 generations. Am J Roentgenol Radium Ther Nucl Med 1959;82:229-38.

3. Bull M, Calderbank P, Ramachandran N. A cause for concern? Osteopoikilosis found incidentally in the emergency department: a case report. Emerg Med J 2007;24:e29 


\section{BMJ Case Reports}

This pdf has been created automatically from the final edited text and images.

Copyright 2011 BMJ Publishing Group. All rights reserved. For permission to reuse any of this content visit http://group.bmj.com/group/rights-licensing/permissions.

BMJ Case Report Fellows may re-use this article for personal use and teaching without any further permission.

Please cite this article as follows (you will need to access the article online to obtain the date of publication).

Hann G, Thust SC, Devereux E. Mysterious but not serious?. BMJ Case Reports 2011;10.1136/bcr.08.2011.4726, date of publication

Become a Fellow of BMJ Case Reports today and you can:

- Submit as many cases as you like

- Enjoy fast sympathetic peer review and rapid publication of accepted articles

- Access all the published articles

- Re-use any of the published material for personal use and teaching without further permission

For information on Institutional Fellowships contact consortiasales@bmjgroup.com

Visit casereports.bmj.com for more articles like this and to become a Fellow 